\title{
Tear electrophoretic changes in Nigerian children after measles
}

\author{
O KOGBE' AND S LIOTET ${ }^{2}$
}

From the 'Department of Ophthalmology, ABU Hospital, Zaria, Nigeria, and 'Laboratoire du Centre National d'Ophtalmologie des Quinze-Vingts, Paris, France

Summary At the laboratory of the National Centre of Ophthalmology, Paris, tear electrophoresis on cellulose acetate support was studied in 56 Nigerian children-32 during and shortly after measles infection and 24 healthy controls. The controls had a normal pattern, while those with measles had patterns consistent with inflammation, most severe in the first week but showing varying degrees of recovery by the third week. Four weeks after measles all cases suffering from malnutrition had patterns with an additional peak. This was shown on further investigation by electrophoresis on polyacrylamide cellulose gel and immunoelectrophoresis to be due to serum transferrin. The normal protein pattern of tears is shown to be altered during and after measles infection.

Clinical observations and reports from Nigeria, ${ }^{1-4}$ Zambia, ${ }^{5}$ Uganda, ${ }^{6}$ Kenya, ${ }^{7}$ and Tanzania ${ }^{8}$ confirm that measles is the commonest cause of corneal ulceration and the leading cause of blindness in children in Africa south of the Sahara. It would appear to be responsible for much of the 200000 annual cases of blindness attributed to xerophthalmia in this region. Measles, which can be very severe in African children, is frequently associated with a rapidly progressive corneal ulceration (up to $1 \%$ in Nigeria $^{3}$ ) and protein calorie malnutrition. This is because most of the children are affected by measles between the ages of 1 and 2 years, which corresponds to their weaning period, when they go off the breast before they can take an adult diet. ${ }^{9}$ During the attack of measles protracted high fevers, severe anorexia, and frequent oral candidiasis worsen the nutritional status of the affected children.

The pathogenesis of this corneal ulceration following measles remains obscure. Its similarity to keratomalacia led to the estimation of serum retinolbinding protein levels. The results have not been significantly decreased in malnourished children with or without measles to support the theory that the condition may be primarily a manifestation of vitamin A deficiency.

Moreover, administering vitamin A, although

Correspondence to Dr O Kogbe, 110 ruc Picrre Brossolettc, 92320 Chatillon, France. effecting an appreciable rise in the concentration of both serum retinol and retinol-binding protein,"' does not, combined with topical antibiotics, accelerate healing of the corneal ulceration, unlike keratomalacia with secondary bacterial infection. Measles" and malnutrition ${ }^{12}$ have separately been observed to cause a state of severe depression in cellular immunity. So it was proposed that the severe corneal ulceration is due to an abnormally severe secondary herpes simplex infection, ${ }^{13}$ calling for a trial of antiviral agents combined with forms of immunotherapy such as interferon or levamisole.

Recent work on the functions of the tear fluid on the cornea in keratitis sicca syndrome suggested the possibility that the lacrimal gland (an epithelial tissue derivative) might be affected by the measles virus.

We investigated the tears produced by children during the course of measles infection by studying the composition and levels of tear proteins.

\section{Materials and methods}

SUBJECTS

In August 1984 and in January 1985 samples of tears were collected from children presenting at the paediatric unit of Ahmadu Bello University Hospital in Zaria and Kaduna, University College Hospital, Ibadan, State Hospital, Ikeja, and Health Centre Tundunwada, Jos. The date of onset of measles, and 


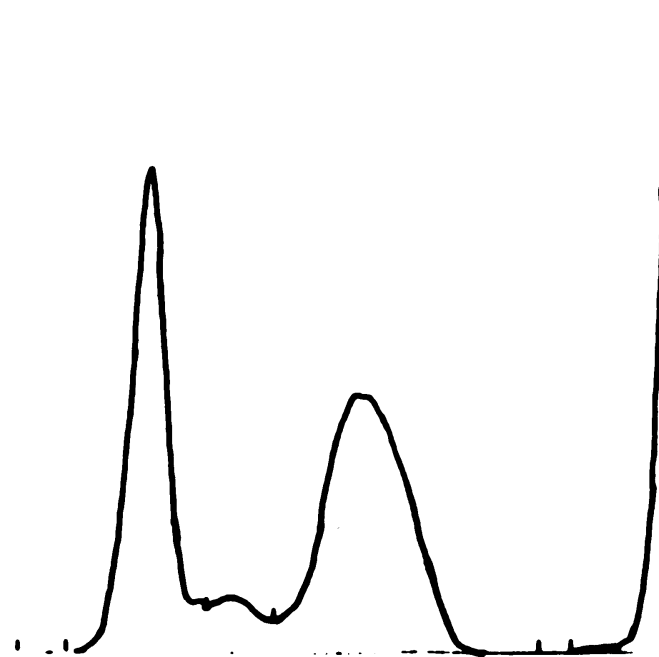

Fig. 1 Control: normal pattern.

its ocular and systemic complications, were recorded. Fifty-six children were seen: 32 had measles, while 24 with no history or clinical evidence of measles served as controls matched for age. The ages of the children ranged between 6 months and 3 years.

\section{METHODS}

Samples of tear fluid were collected by capillarity with a sterile pointed-ground pipette, between $9 \mathrm{am}$ and 12 noon to minimise evaporation, formol vapour being used as a stimulant for lacrimation. The specimens were centrifuged and the supernatant

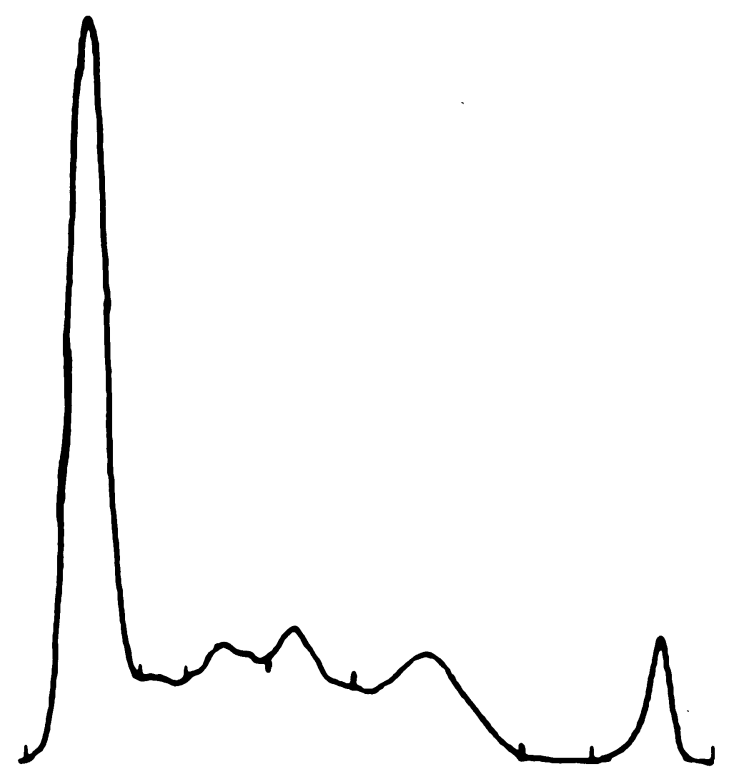

Fig. 2 Measles week 1: serum-like pattern.
1

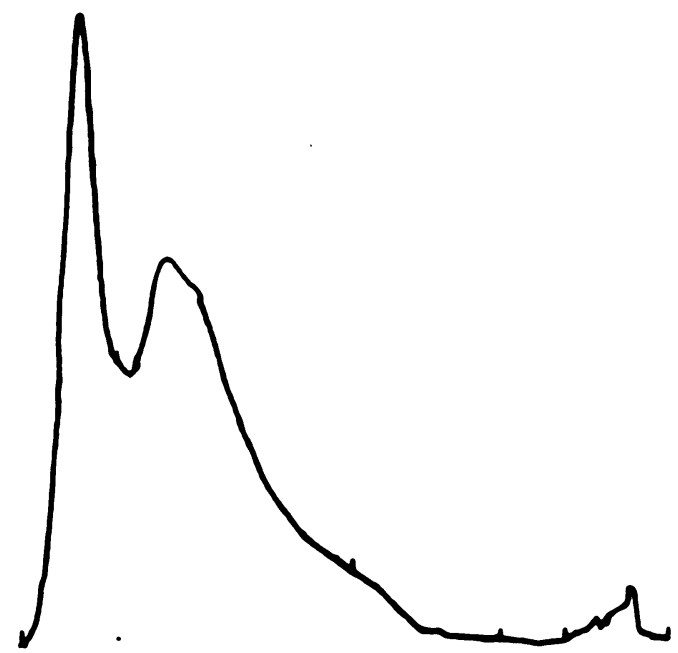

Fig. 3 Measles week 2: type 2 pattern.

stored at $4^{\circ} \mathrm{C}$ until electrophoresis was performed on cellulose acetate support in glycine tris-buffer solution. The strip was stained by Ponceau red, decolorised, and cleared. Further differentiation and identification of proteins was done by carrying out electrophoresis on the polyacrylamide cellulose gel of fresh aliquots of tear samples from cases showing an abnormal change; so also was immunoelectrophoresis of whole serum, diluted serum, and tears in the presence of whole human antiserum on agarose.

\section{Results}

The number of children suffering from measles was surprisingly small, as there had been a successful measles vaccination campaign the year before. Many paediatric units had to be visited to collect tear samples from 56 children. It was generally observed that the controls produced tears much more readily than those suffering from measles.

\section{ELECTROPHORESIS}

All 23 controls had white eyes with no clinical evidence of conjunctivitis. Electrophoresis of their tears showed a splitting into four main bands (Fig. 1). All 19 cases seen during the first week of measles infection had mild to severe conjunctivitis; three had a normal pattern of tear proteins and 16 had patterns similar to that of serum.

During the second week of measles the number of cases seen was much less, as the majority had recovered, and only those with complications reported to the hospital. All seven had mild conjunctivitis. The pattern of tear electrophoresis was still largely similar to that of serum (Fig. 2) in five out of the seven cases, but showed a type 2 pattern (Fig. 3) 


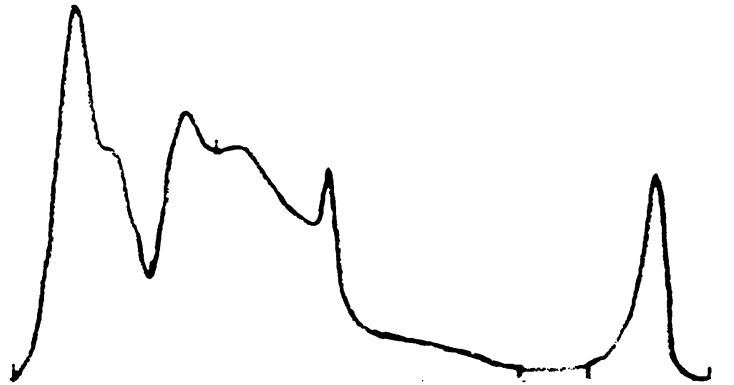

Fig. 4 Abnormalpeak.

abnormality first described by Liotet et al. ${ }^{14}$ One of them had in addition an abnormal peak in the middle band (Fig. 4), indicating an appearance of a new protein.

The only patient whose tears were collected in the third week had recovered from measles. He had no clinical conjunctivitis, and showed a normal pattern of tear electrophoresis. The others seen were too ill and had dry eyes as they just cried noisily without shedding any tears.

All five cases seen at four weeks after measles were on treatment for secondary infections and varying degrees of malnutrition. They had no clinical conjunctivitis but had various corneal erosions. In all five the tear electrophoretic patterns were abnormal, as an additional narrow band with a pointed peak showed up on an otherwise normal pattern in two cases (Fig. 5) and on a serum-like pattern in three cases (Fig. 6).

Whereas five of six malnourished children without a history of measles or corneal disease had patterns similar to the controls', one child who had healing

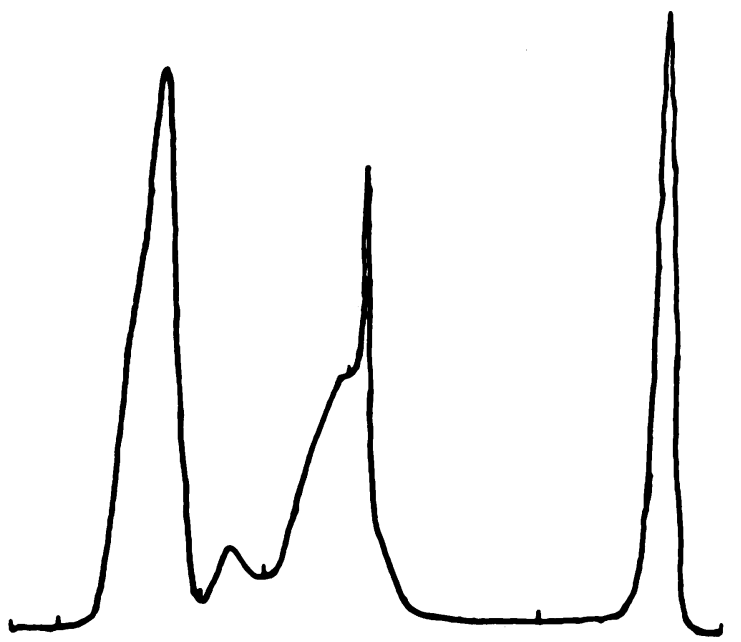

Fig. 5 Abnormal peak.

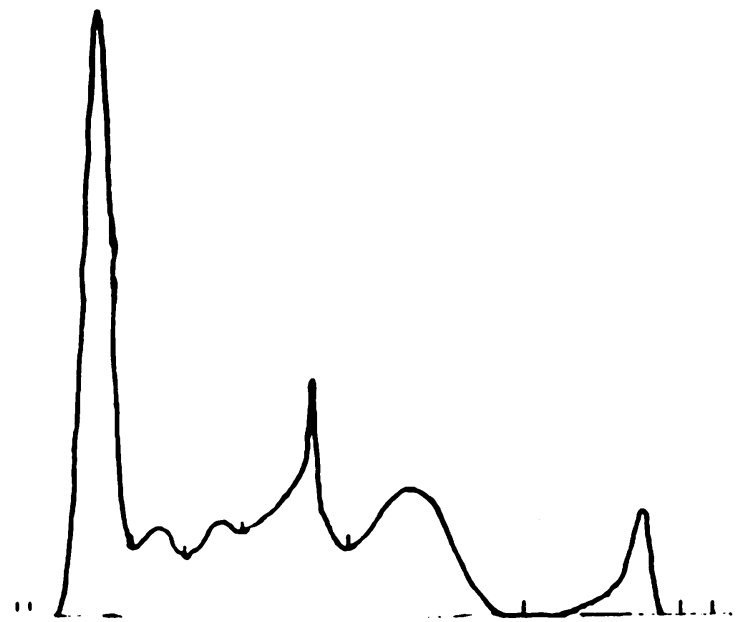

Fig. 6 Abnormal peak.

bilateral corneal ulcerations following meningitis also had an additional band similar to that seen in cases four weeks after measles.

All the tears showing this additional band were examined by electrophoresis on the gel of polyacrylamide cellulose (Fig. 7) and by immunoelectrophoresis (Fig. 8). A prominent band was observed in the position of serum transferrin. We could not determine its quantity as we did not have the specific monovalent antiserum.

\section{Discussion}

The observed reduced tear production in children suffering from measles is highly suggestive of measles affecting the lacrimal gland function in tear production. Not only is the quantity reduced, the quality also appears to be altered.

On normal tear electrophoresis our results agreed with that of Liotet $e t$ al. ${ }^{15}$ who described four bands seen on electrophoresis of normal tears on cellulose acetate support.

During measles the appearance of an electrophoretic pattern like that of serum (Fig. 2) in the presence and absence of clinical conjunctivitis more than confirms McClellan et al.'s experience which led them to say that children with conjunctivitis could be said to be crying serum. ${ }^{16}$

In normal children only a limited amount of serum proteins are found in tears, ${ }^{17-210}$ because a closed blood-tear barrier exists. Hence measles must cause a derangement of this barrier, so that serum proteins move freely into tears from the conjunctival vessels and/or from the lacrimal gland. It is remarkable that this derangement can be detected by tear electrophoresis four weeks after the onset of measles when, 


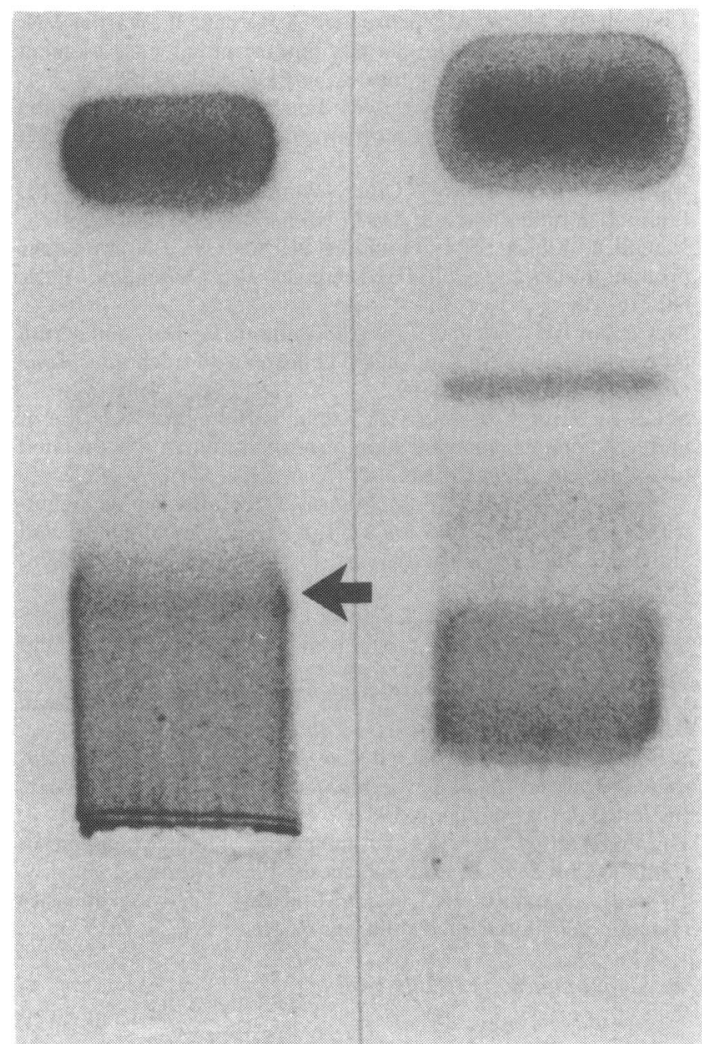

Fig. 7 Serum transferrin band (arrowed).

clinically, recovery from conjunctivitis appears to have taken place. This can either mean that the blood-tear barrier remains open for a while or that the lacrimal gland has not yet recovered. Either way, tear electrophoresis is a simple, non-invasive means of assessing lacrimal gland function and conjunctivitis.

The appearance of serum transferrin in electrophoresis of tears from all children with measles complicated by malnutrition and corneal erosion could be another index of derangement caused by measles. Malnutrition per se cannot be incriminated, as all those affected only by malnutrition had normal patterns. The fact that this derangement was likewise seen in a patient who had not measles but meningitis with malnutrition and healed bilateral corneal ulcerations suggests that the derangement may be the cause or the effect of the corneal lesions. The quantity of serum transferrin is too large (from the peak) to be likely to be due to filtration. So we propose two hypotheses:

(1) The first is local synthesis, which is unlikely, because the usual site of synthesis is in the liver, though this should be considered in view of the reports of synthesis at other sites. ${ }^{21} 22$

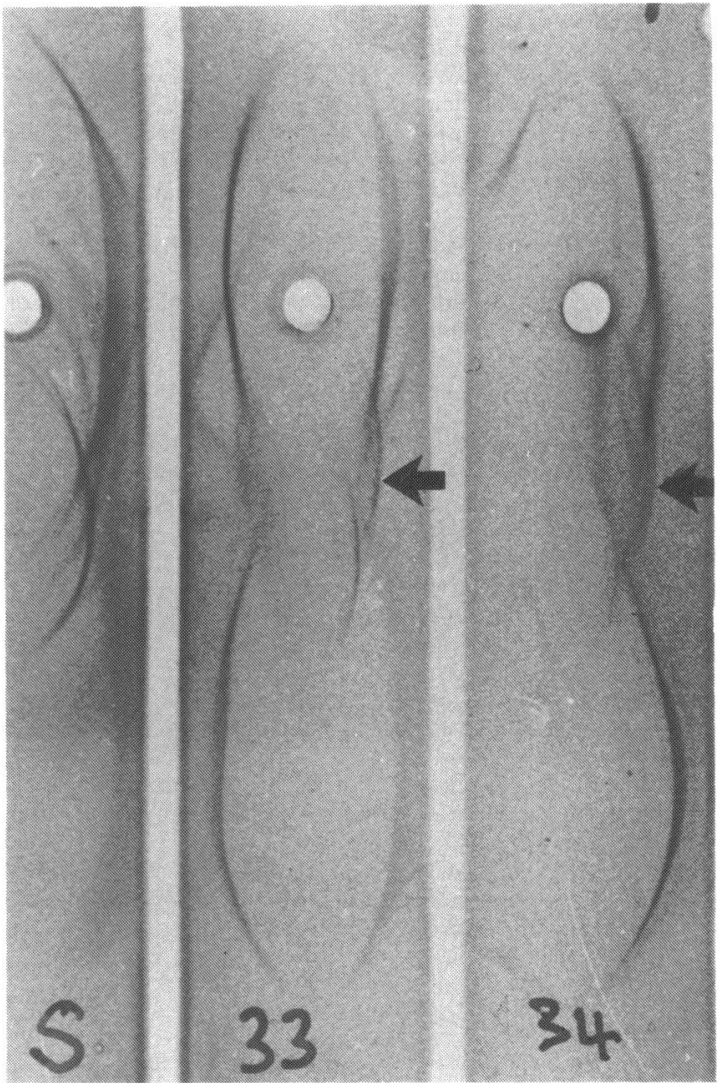

Fig. 8 Serum transferrin band (arrowed).

(2) More likely, there could be an active transport from the vascular sector into the tears. The factor for this is yet unknown, although such observations have been made on the cerebrospinal fluid,,$^{23}$ vitreous, and aqueous humour. ${ }^{24}$ This active transportation of serum transferrin will be a source of loss to the body and may partly explain the finding of low values in malnourished Nigerian children reported by Dossetor et al. ${ }^{25}$

This could explain another means by which measles renders children malnourished. It will be interesting to find out if the same abnormality occurs in liquid secretions and filtrations such as saliva, cerebrospinal fluid, and aqueous humour after measles.

The ready help and co-operation of the staff of the laboratory of the hospital des Quinze-Vingts and the pacdiatric clinics in Nigeria are acknowledged with thanks.

\section{References}

1 Morley DC. The severe measles of West Africa. Proc R Soc Med 1964; 57: 846-9.

2 Olurin O. Etiology of blindness in Nigerian children. Am J Ophthalmol 1970; 70: 533-40. 
3 Animashaun A. Measles and blindness in Nigerian children. Niger J Paediatr 1977: 4: 10-3.

4 Sandford-Smith JH, Whittle HC. Corneal ulceration following measles in Nigerian children. Br J Ophthalmol 1979; 63: 720-4.

5 McGlashan ND. Mcasles, malnutrition and blindness in Luapula Province. Zambia. Trop Geogr Med 1969; 21: 157-62.

6 Bwibo ND. Measles in Uganda. Trop Geogr Med 1970; 22: $167-71$.

7 Moorhoeve AM, Muller S, Schulpen TWJ, Gemert W, Walkenburg HA. Ensering HE Machakos Project studies. Agents affecting health of mother and child in a rural area of Kenya. III. The epidemiology of measles. Trop Geogr Med 1977; 29: $428-40$.

8 Franken S. Measles and xerophthalmia in East Africa. Trop Geogr Med 1974; 26: 39-44.

9 Inua M. Duggan MB. West CE, Whittle HC, Kogbe OI, Sandford-Smith JH, Glover J. Post-measles corneal ulceration in children in northern Nigeria: the role of vitamin A, malnutrition and measles. Ann Trop Paediatr 1983; 3: 181-91.

10) James HO, West CE, Duggan MB, Ngwa MA. Controlled study of the effect of injected water miscible retinol palmitate on plasma concentrations of retinol and retinol-binding-protein in children with measles in Northern Nigeria. Acta Paediatr Scand 1984: 73: 22-8.

11 Whittle HC, Dossetor JBF, Oduloju A, Bryceson ADM, Greenwood BM. Cell mediated immunity during natural measles infection. J Clin Invest 1978; 62: 678-84.

12 Geefhuyse NJ, Rosen EU, Katz J, Ipp T, Metz J. Impaired cellular immunity in kwashiorkor with improvement after therapy. Br Med J 1971; iv: 527.

13 Whittle HC, Sandford-Smith K, Kogbe OI, Dossetor J, Duggan $M$. Severe ulcerative herpes of mouth and eye following measles. Trans R Soc Trop Med Hyg 1979; 73: 66-9.
14 Liotet S, de Murat AF, Schroeder A, Cochet P, Warnet VN, Moens C. Anomalic des larmes entrainant un encrassement rapide des lentilles hydrophiles. Contactologia 1983; 5F: 12-5.

15 Liotet S, Warnet VN. Arrata M. Functional exploration of the lacrimal gland by tear electrophoresis. Ophthalmologica 1982; 184: 87-91.

16 McClellan BH, Whitrey CR, Newman LP, Allansmith M. Immunoglobulins in tears. Am J Ophthalmol 1973; 76: 89-101.

17 McGill J, Liakos GM. Goulding N, Seal DV. Normal tear protein profiles and age-related changes. Br J Ophthalmol 1984; 68: $316-20$.

18 McClellan BH, Bettman JW, Allansmith MR. Tear and serum immunoglobulin levels in Navajo children with trachoma. Am J Ophthalmol 1974; 18: 106-9.

19 Send, K, Sarin S, Mataur GP, Kunal S. Biological variation of immunoglobulins concentration in normal human tears related to age and sex. Acta Ophthalmol (Kbh) 1978; 56: 439-44.

20) Watson RR, Reyes MA, McMauray DN. Influence of malnutrition on the concentration of $\lg A$, lysozyme, amylase and aminopeptidase in children's tears. Proc Soc Exp Biol Med 1978; 157: $215-9$.

21 Thorbeche GJ, Liem HH, Knight S, Cox K, Muller-Eberhard U. Sites of formation of the scrum protein transferrin and hemapexin. J Clin Invest 1973; 52: 725-6.

22 Soltys HD, Brody JI. Synthesis of transferrin by human peripheral blood lymphocytes. J Lab Clin Med 1970; 75: 250-1.

23 Schuller E. In: Baillère JB, ed. Les protéines de liquide céphalorachidien et les maladies immunitaires du système nerveux. Institut Bchring-Medialog, 1981.

24 Dermouchamps JP. Les protéines de l'humeur aqueuse. Catholic University of Louvain, thesis: 1981. Thesis.

25 Dossetor J, Whittle HC, Greenwood BM. Persistent measles infection in malnourished children. Br Med J 1977; i: 1633-5.

Accepted for publication 15 July 1986. 